\title{
Akrasia (swakheid van die wil) en die kontemporêre gesprek oor subjektiwiteit
}

\author{
M.F. Heyns \\ Departement Filosofie \\ Potchefstroomse Universiteit vir $\mathrm{CHO}$ \\ POTCHEFSTROOM
}

\begin{abstract}
Akrasia (weakness of will) and the contemporary discourse on subjectivity

The issue about akrasia (weakness of the will) concerns the question whether the human will is strong enough to choose and realize actions, or whether a conflict, and a certain type of conflict (i.e. the issue of akrasia), will have the potential to paralyse it. My analysis focuses on ideas of thinkers of the last half of the Iwentieth century - thinkers like Skinner who practically denies the existence and strength of the self, and Sartre who postulates a transcendental self with godlike capabilities. I conclude that both leave little room for the idea of akrasia. Akrasia needs a more subtle vision of the power and weakness of the self. To arrive at this conclusion I consider views attempting to reconcile the disempowerment of the self by the extra-self with the idea of a self in control of its situation. I argue that these views fail because they assume the akratic conflict to be between the self and extra-self instead of an intra-will conflict. I also deny that the dialectic goal of a fusion of the self and its situation will give an explanation of the akratic conflict because dialectics still operate with a centred self which assumes a conflict between the centre and a sub-self periphery. Moreover, this kind of dialectics provides the picture of a permanent victimized self rather than an akratic conflict. I conclude by suggesting the existence of a "dense" self with more subjective capacities than is usually assumed. This, I argue, enhances the scope of, and makes the intra-will conflict more credible.
\end{abstract}

\section{Inleiding}

Akrasia (swakheid van die wil) is 'n begrip met 'n veelbewoë geskiedenis - 'n begrip waarvan die bestaan bevestig maar ook fel ontken is. Sokrates se argument in Plato se Protagoras is waarskynlik die argetipe van die radikale verwerping van akrasia. In die Protagoras (Plato, 1982:103-111) word hierdie verwerping voorafgegaan deur wat Sokratres beskryf as die algemeen aanvaarde (tradisionele) definisie van akrasia. Hiervolgens kan iemand se woede, plesier, pyn, liefde of vrees sy kemnis van wat die korrekte handeling moet wees, oorwoeker. Hierteenoor is Sokrates van mening dat kennis die beherende 
element in die kosmos is. Kennis sal geen mens toelaat om, as hy die verskil tussen goed en kwaad ken, enige iets anders as die goeie te doen nie. Sokrates argumenteer dat die illusie dat korttermynplesier groter is as langtermynplesier in die najaag van die goeie, ', 'n mens kan verhoed om kennis van die goeie te hê. Dit wat na akrasia lyk, is dus 'n gebrek aan kennis as gevolg van die krag van voorkoms/illusie (wat 'n karikatuur van kennis is) om 'n mens te mislei. Volgens Walsh (1971:248) suggereer hierdie verwerping van akrasia dat kennis 'n wonderbaarlike mag het om menslike keuses te beheer. Met verwysing na twee tragedies van Euripides (die Medea en die Hippolitus) stel Walsh (1971:252-255) egter dat ' $n$ ander (en bevestigende) verduideliking van akrasia reeds in die tyd van die Klassieke bestaan het. Hierdie verduideliking van die tradisionele siening van akrasia stel dat daar nie enige twyfel is oor wat die goeie en die slegte is nie - goed/sleg is gemeet met in agneming van alle illusies wat die rede kan mislei. 'n Mens is dus seker dat iets sleg is maar verkies nogtans om hierdie redelik gesproke slegter daad te doen. Die gevolgtrekking van hierdie perspektief op akrasia is dat die rede (en dus kennis) beperk is in haar vermoë om die volle waarheid van die kragte wat ' $n$ rol in die mens se lewe speel, te begryp. En selfs al begryp die rede die rasionele waarheid, is dit nie in staat om die mens se lewe ten volle te beheer nie.

Die belangrike geskil in hierdie vroeë debat is dat Sokrates oënskynlik veronderstel dat die mens onder beheer staan van 'n eksterne mag, naamlik kennis, en dat akrasia, wat 'n funksie van 'n kompetente wil is, as gevolg van die krag van die eksterne mag nie moontlik is nie. Hierdie Sokraties-Platoniese gevolgtrekking is ' $n$ antwoord op wat ek die vraag oor akrasia sal noem. Dit is naamlik die vraag of akrasia bestaan al dan nie. Teenoor die Sokraties-Platoniese ontkenning van akrasia veronderstel die Euripideaanse tragedies dat die eksterne druk van kennis nie die enigste faktor is in die bepaling van ' $n$ wilsbesluit nie. Daar is in die Euripideaanse tragedies die suggestie van 'n konflik tussen die goeie en die bose as die hoofkomponent van die verskynsel van akrasia. Hiermee word myns insiens 'n subtiele verskuiwing in die akrasiavraagstuk aangebring wat ek die vraag van akrasia sal noem. Hiervolgens word argumentshalwe aanvaar dat akrasia wel bestaan. Die vraag is egter na die aard van die konflik wat die swakheid van die wil veroorsaak.

In die res van die artikel sal sowel die vraag oor as van akrasia behandel word. Ek sal die vraag oor die bestaan van akrasia benader vanuit die moderne siening van die bestaan van die self. My vermoede is dat die moderne antwoord, net soos die Sokraties-Platoniese siening van akrasia, mank gaan aan die siening van

1 Hierdic redenasie is volgens Plato vergelykbaar met die dricdimensionele illusic dat voorwerpe wat nader is, groter is as voorwerpe wat ver is. 
'n innerlike wilsterkte wat te staan kom teenoor uiterlike kragte, en dat dié twee agente dan tou trek om beheer van iemand se gedrag. Radikale standpunte sal hierdie konflik eenduidig reduseer na óf self-loosheid of die onaantasbaarheid van die self. Dit sal beteken dat akrasia nie moontlik sal wees nie omdat ' $n$ self in innerlike konflik dan nie kan ontstaan nie. In antwoord op die vraag van akrasia sal ek voortbou op die siening dat akrasia verstaan moet word teen die agtergrond van 'n antropologie wat nie kies vir self-loosheid nie, maar ook nie vir 'n absolute outonome en selfskeppende self nie. Ek sal veral argumenteer dat die konflik tussen innerlik en uiterlik nie die spanning kan wees wat betrokke is in die funksionering van akrasia nie. Ek sal, hierteenoor, eerder stel dat akrasia die verlamming is van die vermoë om besluite/ oortuigings uit te leef as gevolg van spanning tussen die pluraliteit van menslike vermoens oor die (goeie of slegte) rigting van haar lewe.

Taylor (1988:313-314; 1989a:127-130; 134-138) wys daarop dat Augustinus se siening van die wil die moontlikheid van akrasia voorsien. Die Augustiniaanse siening het drie voedingsbronne:

- Deels is die Augustiniaanse siening die gevolg van die Stoïsynse leer dat die mens die vermoë het om te kies.

- Tweedens, hoewel die Sokraties-Platoniese tradisie gepoog het om die self te konstrueer rondom die rede, het Plato nie 'n konsep gehad van die innerlike van die mens nie. Dit was Augustinus wat 'n radikale innerlikheid in die Westerse siening van die mens gevestig het. Hierdie verinnerliking van die self gaan hand aan hand met 'n sterker bewustheid van wat beskou word as die bestaan van die wil: die mens se vermoë om te kies, is geleë in die innerlike.

- Die derde motief vir die leer van akrasia by Augustinus is die Christelike siening dat die mens in staat is tot twee radikaal teenoorstaande morele geneigdhede. Hierdie motief gee altyd aanleiding tot die vraag of 'n bepaalde begeerte of aksie sy oorsprong het in 'n goeie of slegte wil.

Op grond van hierdie kenmerke van die Augustiniaanse tradisie kan afgelei word dat die probleem oor akrasia die aannames by die etiese probleem van toerekenbaarheid skerp belig. Kan 'n persoon vir sy gedrag verantwoordelik gehou word as hy aanvoer dat hy opgetree het onder die invloed van 'n swak wil? En selfs al kan iemand aandui dat sy optrede beinvloed is deur 'n swak wil, kan hy nie dalk verantwoordelik gehou word vir die swakheid van sy wil nie, of is akrasia genoegsame rede om verantwoordelikheid vir aksies vry te spring? Die vraag oor die bestaan van akrasia het egter sedert Augustinus ook 'n sterk antropologiese tema geword deurdat daardie elemente van die mens en sy situasie wat swakheid van die wil moontlik maak, onder die vergrootglas gekom het. Dit 
is veral die vraag oor die bestaan van 'n innerlike self met die vermoë of krag om iemand se gedrag fundamenteel te bepaal, wat in die moderne tyd al meer akuut geword het. Die vraag of iemand 'sterk' genoeg is om besluite te neem en deur te voer, is sekerlik een van die belangrikste voorvrae of veronderstellings in die beskrywing en beoordeling van menslike gedrag in die menswetenskappe, want die vraag na die oorsake van gedrag is in die sentrum van besinning in die menswetenskappe. Akrasia veronderstel dat die innerlike vermoë om 'n wilskeuse te maak 'verlam' word. Die vraag van akrasia veronderstel in dié lig dan ' $n$ antwoord oor wat die verlamming veroorsaak. Dit is op hierdie anatomie van die wil waarop hierdie artikel sal ingaan eerder as die meer etiese vrae wat hierbo genoem is.

\section{Die vraag oor akrasia}

\subsection{Behavioristiese selfloosheid en akrasia}

Die Sokraties-Platoniese tradisie se eenduidige ontkenning van akrasia, sê Taylor (1989a:138), word in ons tyd voortgesit deur moderne naturaliste. Die motivering vir hierdie moderne standpunt kan onder andere gevind word in ' $n$ invloedryke denker soos die behavioristiese psigoloog, B.F. Skinner, se standpunt oor die self en menslike gedrag. Hoewel hy nie die term akrasia direk gebruik nie, is sy opmerkings oor die bestaan van die self en self-beheer ${ }^{2}$ direk van toepassing op die probleem oor die swakheid van die wil. Volgens Skinner (1972a:184, 188, 198,205 ) is dit oorerflike eienskappe (tot 'n mate), maar veral die omgewing wat menslike gedrag bepaal, en nie die wil/self nie. Die tradisionele siening van die persoon (soos Skinner dit noem), naamlik dat die persoon sy omgewing beheer, is gebaseer op foutiewe aannames en kan nie in 'n wetenskaplike eeu gevolg word nie. Sy eie ontkenning van die invloed van die self is natuurlik die gevolg van Skinner se positiwistiese siening van wetenskap. Skinner (1972a:200-201, 211; 1972b:51-52) stel dat die idee van 'n outonome mens gewortel is in die illusie van die innerlike mens, die homunculus. Hierdie konsep is bloot die produk van die 'literatuur van vryheid en waardigheid van die menslike persoon'. Die homunculus word benodig om onverklaarbaarhede wat nie op wetenskaplike manier verklaar kan word nie, te verduidelik. Maar soos wetenskaplike kennis groei, verdwyn die behoefte aan die innerlike dimensie want daar is dan oorgenoeg waarneembare, natuurlike en manipuleerbare data om gedrag te verklaar.

2 Vir die docleindes van hierdie artikel word die skryfwyse self-beheer, self-loos, cnsovoorts gebruik om daardeur dic filosofiese reifiscring van die konsep self te benadruk 
Die standaardkritiek teen hierdie standpunt is dat dit onderliggend uitgaan van ' $n$ volledige redusering van die mens tot materialistiese en kousale substansies en wette wat geen ruimte laat vir nie-materiele komponente en vermoëns soos die wil nie. Hiermee saam lyk Skinner se aanname dat dit veral die omgewing is wat gedrag bepaal, taamlik bevooroordeeld - selfs iets materialisties soos genetiese afstamming het veel meer invloed op die wyse waarop mense optree as wat Skinner wil toegee. Daarmee is nog nie eens gevra wat die invloed is van die individu se eie wil in die saak nie (Botha, 1990:132, Evans, 1979:25-27, Stevenson, 1981:97, 102). Dit is egter nie asof Skinner geen plek maak vir ' $n$ begrip soos die self nie. Hy interpreteer egter die idee van die self op so 'n wyse dat dit in praktyk op ' $n$ amper weglaatbare swak self neerkom. Die self is volgens Skinner (1972a:199) bloot 'n repertoire van gedrag wat pas by 'n gegewe stel situasies. Daarom is selfs meer as een self moontlik - 'n repertoire vir ' $n$ mens se lewe saam met sy gesin, 'n ander repertoire vir sy lewe saam met sy vriende, ensovoorts. Dit is dus te verstane dat Skinner (1972a:190-192) 'n selfaksie wat tradisioneel uitsluitlik an die innerlike self toegeken is, naamlik introspeksie, nie as die werk van die outonome mens sien nie, maar as 'n sosiale produk. Dieselfde geld die begrip self-beheer - dit is die begrip waarmee Skinner die naaste kom aan die tradisionele begrip van die wil. Self-beheer is in die geheel gesien niks anders as 'n sosiale produk nie. Volgens Skinner (1972a: 194$195,197-199$ ) is dit die omgewing wat die gedrag vorm waarmee mense hul probleme oplos. In dié verband wys hy op bekende konsepsies van die beherende self, naamlik terme soos bewussyn of super-ego wat ten diepste konstrukte is met 'n sosiale oorsprong. Skinner (1972b:55) maak met hierdie aanname in die agterkop die stelling dat die noodsaak vir self-beheer en persoonlike verantwoordelikheid (wat meesal met die tradisionele siening van die self of persoon geassosieer word) grootliks verminder kan word deur die regte omgewing te skep. Tegnologie kan oorlog byvoorbeeld oorbodig maak - heldhaftigheid is dus nie meer nodig nie. So ook hoef psigiese krag en self-beheer nie vertoon te word wanneer 'n persoon ly as gevolg van enstige mediese toestande nie omdat die mediese wetenskap lyding toenemend uitskakel. Dit beteken dat die verskynsel waar die wil die swakheid van lafhartigheid vertoon, ' $n$ irrelevante moontlikheid word.

Tog, ten spyte van hierdie relatief radikale aanname van 'n self-loosheid van die mens en die gevolglike irrelevante konsep van die funksionering van die wil in die vorm van self-beheer, is daar tog ' $n$ terugkrabbeling wat Skinner op die drumpel van 'n paradoks laat beland. Skinner (1972b:205) stel naamlik dat die feit dat die outonome mens algaande beheer verloor ten gunste van beheer deur die omgewing en ander mense, aan hom die beeld van 'n 'slagoffer' gee. Hierop antwoord Skinner dat die mens ook wel die 'aanvaller' kan wees. Die mens is immers die skepper van sy eie omgewing deur middel van sy wetenskaplike en tegnologiese beheer oor die wêreld waarin hy woon. Dit maak die mens 'n 
beheerder van homself. Skinner is bewus daarvan dat hy besig is om die sterk self ' $n$ kans te gee om weer ' $n$ (onopsigtelike) rol te speel. Daarom stel hy dat hy nie 'n pleitbesorger vir 'n kru vorm van individualisme wil wees nie. Die selfbeheer wat hy voorstaan, moet bemiddel word deur die kulturele evolusieproses wat veel groter is as die individuele persoon. Botha (1990:136) is egter van mening dat Skinner nie die paradoks sal kan ontkom nie: aan die een kant word die mens gesien as 'n wese wat deur sy omgewing gedetermineer is, maar aan die ander kant wil Skinner die mens tot groter hoogtes van vryheid voer met sy wetenskaplike metodes. Dus, hoewel Skinner die bestaan van die verinnerlikte self sover moontlik probeer vermy, is die verskyning van spanning tussen subjektiewe vermoë en die omgewing 'n teken daarvan dat hy steeds die gevangene is van hierdie Augustiniaanse konstruk.

Daarmee saam kan gestel word dat die tradisie om sekere gedrag aan akrasia toe te skryf, ook nie in die doofpot van die moderne wetenskaplike en tegnologiese kultuur sal verdwyn nie. Die implikasie van self-loosheid is 'n ontkenning van die verskynsel van akrasia. Omdat geen sterk genoeg wil wat menslike gedrag bepaal, kan bestaan nie en alle gedrag die gevolg is van omgewingsfaktore, word die idee dat ' $n$ andersins sterk wil swak kan optree, irrelevant. Die konsep van self-loosheid is egter iets wat onder verdenking kan kom. Akrasia is dus iets wat steeds oorweeg kan word omdat die veronderstelling geldig is dat 'n subjektiewe vermoë wat die oorsprong is van besluite/oortuigings en die uitvoer daarvan, kan bestaan. Maar selfs al bring Skinner die self op halfhartige wyse terug in die prentjie, sal dit nog nie akrasia moontlik maak nie omdat die idee van 'n konflik tussen die self en buite-self ' $n$ oorheersende rol in sy denke speel - hierdie aspek word vervolgens in meer besonderhede bespreek

\subsection{Akrasia en die transendentale self}

Die interessante van die verskynsel van akrasia is dat die teenoorgestelde van self-loosheid, naamlik 'n oordrewe sterk self/wil ook neig om die verskynsel van akrasia te ontken. Maar weereens sal die sterk wil wat akrasia onmoontlik maak, geproblematiseer kan word. In dié verband kan kortliks gekyk word na die transendentale self wat die Franse eksistensie-filosoof J.-P. Sartre veronderstel.

In die kem van Sartre $(1990: 33-34,47,52)$ se siening of definisie van die mens is die stelling dat die mens vry is. Dit beteken veral dat die mens aan geen determinerende aprioriese norme onderworpe is nie. Positief beteken hierdie vryheid van Sartre $(1990: 44,50,55)$ dat die mens homself deur middel van sy eie aksie definieer. Menswees beteken dat dit wat die mens op enige bepaalde moment is, getransendeer moet word - daar is geen menslike realiteit, behalwe in aksie nie. Om hierdie kern van vryheid en aksie moontlik te maak, gaan Sartre (1990:44) uit van 'n ekstreme subjektiwisme in die vorm van 'n transendentale self. Meer spesifiek het die Cartesiaanse cogito ("ek dink daarom is ek" - die 
mens se onbemiddelde bewussyn van homself) vir Sartre besondere aantrekkingskrag. Hiermee saam moet genoem word dat Sartre $(1990: 27-28,39,54)$ die absolute transendente subjek, God, afskaf. Teìsme veronderstel 'n skepper-God wat volgens 'n aprioriese plan skep - dit wil sê 'n essensie wat aan die mens 'n menslike natuur gee, word veronderstel. So 'n veronderstelling sou egter die absolute keuse en kreatiwiteit van die cogito verswak en daarom is die niebestaan van God tegelyk ook die moontlikheid vir absolute transendentale menslike subjektiwiteit. Dit is die betekenis van Sartre se bekende uitspraak, naamlik dat by die mens sy eksistensie sy essensie voorafgaan - daar is geen menslike natuur nie omdat die god wat dit aan die mens sou gee, nie bestaan nie. En die morele norme waarvolgens die mens moet leef, is ewe-eens iets wat nie kan bestaan as God nie bestaan nie. Daarom is die mens in die situasie dat hy sy eie norme en waardes moet ontwerp of skep deur 'n radikale keuse uit te oefen. Die belangrikste konsekwensie van hierdie radikale subjektiwisme, volgens Sartre (1990:29-32), is dat die mens vir homself verantwoordelikheid moet aanvaar. En wat meer is, die individu se verantwoordelikheid word wyer gesien - hy aanvaar met elke keuse wat hy maak verantwoordelikheid vir die ganse mensdom, elke keuse is bindend vir alle mense. Samevattend kan gestel word dat Sartre 'n sterk self of wil veronderstel - so sterk dat hierdie self die transendentale skepper van sigself en sy omgewing word.

Dit is op hierdie punt waar Sartre se ekwivalent van akrasia oorweeg moet word. Die geweldige verantwoordelikheid wat die individu opgelê is (hy moet selfs vir die ganse mensdom kies), veroorsaak angs by die mens, sê Sartre (1990:30, 5052). Hierdie angs is die agtergrond waarteen Sartre se bekende konsep van 'kwade/slegte trou' gesien moet word. Soms kan mense poog om die angs te ontkom deur middel van selfbedrog. Hy/sy kan probeer om die self te verskoon van die verantwoordelikheid deur agter hartstogte, of een of ander deterministiese leerstelling, of 'n stel opgelegde waardes/norme te probeer skuil. Dit is egter 'n valsheid, 'n logiese fout wat die basiese menslike situasie van vryheid en verantwoordelikheid probeer ontken. Maar dit is ook meer as dit - dit is ook 'n morele fout. Vryheid ter wille van vryheid is 'n morele verpligting, en dit is 'kwade trou' om hierdie plig te probeer ontkom. Die standaardkritiek teen hierdie voorstelling van 'n morele verpligting en die oordeel dat die nie-nakoming daarvan neerkom op 'slegte trou' is dat dit Sartre se poging weerspreek om die mens absoluut vry en sonder morele verpligting te verklaar (Klapwijk, 1987:122123; Stevenson, 1981:88-89). Sartre $(1990: 48,52)$ erken self dat hy wel hier 'n enkele onoortreebare universele norm voorhou, naamlik dat dit nie moontlik is om nie te kies nie - om nie te kies nie is ook ' $n$ keuse. Die verdere probleem van hierdie paradoks is die vraag waarom Sartre homself net beperk tot dié enkele morele voorskrif - dit lyk arbitrêr. As Sartre die paradoks wil oplos, sal hy afstand moet doen van of die absoluut transendentaal skeppende self of van die yl moraliteit waaraan hy wel vashou. Net soos in die geval van Skinner se self- 
Akrasia en die kontemporêre gesprek oor subjektiwiteit

loosheid waar ruimte gelaat word vir die moontlikheid van 'n self, huldig Sartre 'n effektiewe kontekslosheid (wat neig in die rigting van 'n konteks-loosheid) maar moet hy ten laaste toegee dat die buite-self (morele voorskrifte) tog wel 'n invloed op 'n mens se gedrag sal kan uitoefen.

Indien Sartre se konsep van 'kwade trou' as 'n verduideliking van akrasia gesien word, is dit opmerklik dat dit, net soos Skinner se begrip 'self-beheer', steeds vasgevang is in 'n spanning tussen die self en omgewing. Taylor argumenteer op effektiewe wyse dat die soort konteksloosheid wat Sartre voorstaan, vryheid eintlik absurd maak. Taylor verwys na die verhaal wat Sartre (1990:35-38, 4950) vertel van 'n student wat gedurende die Tweede Wêreldoorlog verskeur was tussen die keuse of hy by sy moeder moes bly wat emosioneel totaal afhanklik was van hom, en of hy by die weerstandsbeweging moes aansluit. Die keuse is tussen sy liefde en lojaliteit aan sy moeder of patriotisme. Volgens sy leer van radikale vryheid en verantwoordelikheid is Sartre se oordeel dat nie hy of enige jemand anders vir die jong man die besluit kan neem nie; daar is geen algemene morele reel wat hom kan help om die besluit te neem nie. Dit beteken dat die jong man die morele reel wat van toepassing is op sy situasie, self moes ontwerp deur te kies. Volgens Taylor (1985:29) veronderstel Sartre hier 'n radikale keuse, dit wil sê 'n keuse wat nie gegrond is op enige redes waarom die keuse gemaak word nie. As dit Sartre se posisie is, is die skets van die jong man se dilemma egter iets wat Sartre se siening van morele keuses ondermyn, want in der waarheid veronderstel die man twee morele aansprake wat van buite die self op hom inwerk. Die twee alternatiewe, naamlik patriotisme of liefde vir sy moeder, is nie twee waardes wat die man bloot deur middel van ' $n$ radikale keuse in aansyn sou kon roep nie. As dit so sou wees, kon hy enige tyd van die dilemma ontslae geraak het deur bloot een van die alternatiewe as nie-geldig te verklaar. In die geval van Sartre is die spanning tussen self en situasie gebaseer op 'n ondraaglike weerspreking. 'n Sterk wil in die vorm van 'n absolute vrye self staan teenoor die buite-self en eis dat vryheid hoegenaamd nie ingeperk mag word nie. Enige inperking sal deur Sartre as 'kwade trou' beskryf word. Tog is die eis vir absolute vryheid iets wat vir die self gegee is deur die buite-self. Sartre se transendentale self kan dus geinterpreteer word as 'n self wat ook deur die buite-self beheer word.

As ons uitgaan van die standpunt van 'n transendentale self wat morele norme kan skep bloot deur dit te wil of te kies, word morele dilemmas onmoontlik - en daarmee saam die verskynsel van akrasia, want akrasia veronderstel altyd 'n dilemma. Akrasia verg 'n subtiele siening van 'n self in konflik met homself. 'n Be-mag-tigde self word per definisie benodig om akrasia moontlik te maak - die soort selfloosheid van Skinner maak akrasia onmoontlik. Tog dui akrasia ook op 'n momentele situasie waar die wil te swak is om 'n gekose/ ge-wil-de aksie uit te voer - waar die nodige energie om die gekose daad uit te voer, nie in werking 
gestel word nie. Om 'n transendentale self wat nie in so 'n situasie kan beland nie te verwag, sou ewe-eens neig in die rigting van die ontkenning van akrasia. Die voorwaarde vir die bestaan van akrasia kan daarom soos volg saamgevat word: akrasia word ondervind in daardie situasies waar iemand homself as in beginsel nie-magteloos ervaar, maar terselfdertyd ook nie as in totale beheer van sy aksies nie.

\section{Die vraag van akrasia}

\subsection{Die parsialistiese benadering tot akrasia}

Die gene wat die self ontken en hulle wat 'n absolute self stel, het 'n oorvereenvoudigde siening van die vermoëns van die mens. Hulle gaan naamlik uit van die standpunt dat die mens in alle gevalle óf die wil en vermoe het om 'n bepaalde daad uit te voer, óf dat die mens hierdie vermoë nie het nie en volledig van buite die wil van die mens om gedetermineer word. Hierteenoor veronderstel die idee van akrasia 'n veel komplekser en selfs paradoksale situasie: die mens is sowel in staat en ontmag om sy wil in dade om te skakel. Volgens Rorty $(1980: 194,205-206,209-210)$ is sodanige mens 'n persoon in konflik en kontradiksie. Indien aanvaar word dat akrasia wel bestaan, is die belangrike opvolgvraag na die aard van die konflik van die wil by die akratiese mens - dit is die vraag van akrasia. Watson (1977:326-327) argumenteer dat die dwang wat 'n mens van 'buite' homself ervaar, hom kan dwing om anders op te tree as dit wat hy oordeel die regte daad te wees. In hierdie geval is dit nie soseer dat die wil te swak is, as wat die eksterne krag te sterk is nie. Hierteenoor is die tradisionele siening van akrasia (wat Watson nie onderskryf nie) dat die mens handel teen sy eie oordeel van wat gedoen behoort te word terwyl hy wel in staat is om volgens sy eie oordeel op te tree. In laasgenoemde geval val die klem in akrasia op die wil self - die konflik wat die wil verhoed om sy gekose daad uit te voer, is iets wat oenskynlik binne die wil self afspeel. 'n Ander moontlike verklaring vir akrasia (wat nie die idee van 'n intra-wil-konflik onderskryf nie) is om te stel dat akrasia deur 'n soort versoening tussen die sienings van 'n uiters swak en uiters sterk wil tot stand gebring sou kon word. Ek sal die eksponente van hierdie oplossing 'parsialiste' noem na aanleiding van die beeld van 'n ontologies gegewe parsiële sterk wil of parsiële swak wil. Laasgenoemde alternatiewe is basies dieselfde - met die enigste verskil dat die hoek van waanuit akrasia benader word (vanaf die kant van die wil of vanuit die hoek van 'n weglaatbare swak wil), verander.

Die benadering vanuit die hoek van 'n konstitusioneel swak wil is een waarin gepoog word om die behavioristiese ontkenning van die self en dus van akrasia, te versoen met die erkenning van akrasia/ bestaan van die eie wil. Watson (1977: 326-327) stel dat hy nie die tradisionele akrasiakonsep onderskryf nie, naamlik dat die akratiese mens die vermoë het om self-beheer toe te pas maar dit nie wil 
uitoefen nie. Ten einde sy posisie te verstaan moet sy onderskeid tussen die wil en kompulsies in ag geneem word. Hy identifiseer die wil volledig met die oordeel van iemand oor wat die regte daad sou wees. 'n Kompulsie hierteenoor is ' $n$ drang wat, soos dwang van buite die persoon, hom dwing om te handel teen sy oordeel van wat die regte daad is. Op tipies behavioristiese wyse argumenteer Watson egter dat sowel swakheid van die wil as 'n kompulsie net gemeet kan word aan die uitkoms daarvan in dade. Net soos by 'n kompulsie is die definisie van akrasia ook dat iemand teen sy oordeel van wat die beste is, handel - daar is dus oënskynlik geen verskil tussen 'n kompulsie en akrasia nie. Volgens die tradisionele konsep van akrasia sou die verskil wees dat akratiese gedrag sy oorsprong in die wil het, terwyl 'n kompulsie sy oorsprong buite die self/wil het. Watson probeer egter om die idee van ' $n$ inisiërende self/wil te systap. Watson (1977:323, 330-332) klink soos Skinner as hy stel dat die antwoord op die vraag waarom akrasia voorkom, gelee is in die konsep 'self-beheer'. Self-beheer veronderstel dat uiteindelik wel 'n verskil tussen kompulsies en akrasia gemaak kan word. Hy argumenteer dat mense in die normale proses van sosialisering sekere vermoëns aankweek wat die drang om teen die beter oordeel op te tree, kan weerstaan. Hierdie aanname is inderdaad die Skinnereaanse skepping van 'n self met 'n aangeleerde repertoire van probleemoplossende potensialiteite. Akrasia is om op te tree op 'n manier wat hierdie normale aangekweekte vermoëns weerspreek. 'n Kompulsie daarenteen is om gekonfronteer te wees met eksterne dwang wat die normale vermoëns van weerstand nie kan hanteer nie. Watson (1977:333-336) verduidelik dat die akratiese persoon in gebreke gebly het om sekere normale kapasiteite van self-beheer te ontwikkel en in stand te hou. Mele (1986:678) huldig min of meer dieselfde standpunt. Hy stel voor dat die persoon sy omstandighede moet manipuleer deur sekere strategieë te ontwikkel waardeur hy sy motivering verhoog om die gekose aksie uit te voer.

In albei hierdie outeurs se gevalle word die akratiese persoon slegs verantwoordelik gehou vir die maatreëls wat hy vooraf tref, maar word hy in der waarheid verskoon vir die swakheid van wil wat hy ten tyde van die daad vertoon. Daar word dus veronderstel dat die self/wil tydens die daad van akrasia in elk geval prakties gesproke nie bestaan nie. Die grootste probleem van hierdie siening is dat die oorsaak vir akrasia nog nie opgelos is nie want die vraag kan gevra word waarom die persoon nie die nodige maatreêls getref het om 'n omgewing te skep wat sy motivering tydens die daad kon ondersteun nie. Die sekondêre akrasia wat hier ontstaan, moet nog verklaar word. Dit kan met 'n tersiêre akrasia verklaar word, en dié met 'n vierde en vyfde vlak van akrasia. Die semi-behavioristiese verklaring van akrasia kan nie die denkfout van oneindige retirering ontkom nie. Myns insiens is die rede vir hierdie ineenstorting van die verklaring van akrasia die behavioristiese poging om gedrag te verklaar sonder verwysing na 'n wilsvermoë wat die oorsprong van 'n daad kan wees. 
M.F. Heyns

Tog veronderstel die parsieel-behavioristiese verklaring van akrasia, soos dié van Skinner, 'n self/wil. Die self het dus, soos by Skinner, terloops aandag ontvang. Daarom word die fokus geplaas op 'n konflik wat die self ervaar as gevolg van eksterne druk wat op hom toegepas word. Die vraag is of 'n benadering wat meer klem lê op die rol van die wil akrasia werklik 'n self-konflik sal kan maak in plaas van 'n self versus 'n konflik van die buite-self. 'n Voorbeeld van iemand wat akrasia vanuit die rigting van die bestaan van die self benader, is Rorty (1980:204-209) wat stel dat akrasia 'n standaardpersoon veronderstel met normale intellektuele en emosionele vermoëns om volgens sy wil op te tree. Sy erken dat die kriteria vir 'normaal' 'n onpresiese saak is wat kultureel kan verskil Maar sy is tog van mening dat daar sommige kriteria is wat kultuur transendeer en meer universeel van aard is - 'n soort transendentale self is dus moontlik. Sy stel verder dat akrasia niks meer mag wees as 'n tydelike en gelokaliseerde swakheid van die wil nie. Iemand wat deur en deur akraties is, sal uiteindelik nie meer kwalifiseer as 'n kompetente persoon wat wilsbesluite kan neem en daarvolgens optree nie. Wat meer is, selfs as iemand sy/haar tydelike en gelokaliseerde wilswakte ervaar, skryf sy dit eintlik toe aan die funksionering van die wil. Die akratiese persoon, sê Rorty, is iemand wat in konflik is omdat hy/sy keuses sien waar ander mense gerig word deur hul min of meer outomatiese gewoontes. Wanneer sy redes gee waarom iemand besluit op die akratiese alternatief, lyk dit egter of sy die skuld toeskryf aan omgewingsfaktore. Sy stel byvoorbeeld dat die akratiese alternatief meer aanloklik lyk as die aanvanklike keuse omdat die wêreld die akratiese persoon nie gaan toelaat om sy aanvanklike keuse uit te voer nie. Of dit kan wees dat hy nie die nodige kreatiewe en perseptuele vermoëns aangeleer het om sy gekose aksie duidelik en helder vir homself voor te stel nie - 'n gebrek aan omstandigheidsfaktore soos opvoeding of ervaring wat aan hom dus 'n sterk wil sou gee. Dit kan ook wees dat 'n persoon hom in 'n sosiale of politieke situasie bevind wat sy gekose keuse vir hom onmoonlik laat lyk en hom dus die gevoel van magteloosheid gee.

Die prentjie wat Rorty vir ons skets, is die van 'n sterk self wat by geleentheid/ uitsondering 'n swakheid van die wil ervaar. Die aanloop tot so 'n ervaring is 'n konflik wat by die mens ontstaan omdat sy 'n keuse moet maak tussen twee alternatiewe; die een keuse haar voorkeur en die ander wat sy as verwerplik ervaar. Sy kies uiteindelik die verwerplike omdat sy druk van die omgewing ervaar om die keuse uit te oefen. Die rede waarom 'n mens die akratiese optrede as onbevredigend ervaar, is omdat dit haar laat twyfel aan haar kwalifikasies as 'n kompetente persoon wat in beheer van haarself is. Die akratiese konflik is in die geval van Rorty dus ook 'n innerlik-uiterlike spanning. Om die aantrekkingskrag van die akratiese alternatief te vermy, maak Rorty (1980:210) 'n voorstel wat baie naby aan dié van Watson en Mele is. Die akratiese mens moet naamlik sorg dat haar fokus sterker op die gekose alternatief en diè se aantrekkingskrag is. Dit beteken dat die akratiese mens, sodra sy bewus is van die druk wat sy vanuit die 
omgewing gaan ervaar om 'n nie-gekose aksie uit te voer, sekondêre stappe sal neem om haar wil te ondersteun sodat die druk maklik verwerk kan word ten tyde van die primêre aksie. Weereens egter is die vraag waarom 'n akratiese persoon, as sy nie die stappe geneem het nie, dit nie geneem het nie. Ook Rorty sal nie die gevaar van oneindige retirering na meer fundamentele oorsake kan vermy nie

Die eensydigheid van die behaviorisme en Sartreaanse transendentalisme kan nie werklik 'n definisie van akrasia vir ons gee nie omdat hierdie sienings van die mens in hul ekstreme vorme nie 'n konflik van die intra-wil kan voorstel nie. Die definisie van akrasia waarmee die parsialiste ons laat, is van 'n self wat in kompetisie is met haar omgewing. Die self wil een soort aksie uitvoer terwyl die omgewing die self probeer dwing om op ' $n$ ander wyse te reageer. Die vraag is dus wie die sterkste gaan wees; die wil van die self of die druk van die omgewing. Parsialiste wat neig in die rigting van die behaviorisme, sal heelwat meer akrasia verunderstel as parsialiste wat neig in die rigting van die Sartreaanse siening. Maar gemeenskaplik aan albei is 'n siening van akrasia as iets wat sy oorsprong het in die konflik tussen die self en haar omgewing. Akrasia is volgens hierdie definisie die ineenstorting van die wil as gevolg van eksterne druk. Dit bring ons egter terug by die vraag oor akrasia (bestaan akrasia of nie?): is die siening dat die self as gevolg van eksterne druk nie sy gekose taak uitvoer nie, werklik akrasia? Is dit nie bloot 'n kwessie van die wil wat nie die nodige wilsvermoe besit nie en eventueel maar moet toegee nie? Hierteenoor veronderstel die tradisionele definisie van akrasia die komplekse situasie van 'n kompetente wil wat 'n verlammende konflik in sigself ervaar.

\subsection{Die dialektiese self}

Die parsialistiese verklaring van akrasia is niks anders as om 'n dualisme tussen wil en omgewing te veronderstel nie. 'n Invloedryke poging in die geskiedenis van die Westerse denke om hierdie tipe dualisme te oorkom, is deur middel van 'n dialektiese monisme. Dit is die poging om die twee pole deur middel van 'n dialektiese spel ineen te laat smelt. Volgens hierdie hipotese sou self en buiteself ' $n$ eenheid vorm en sou akrasia weer moontlik word omdat die konflik binne die eenheid plaasvind en nie 'n akrasia-ontkennende eksteme konflik sou wees nie. Die vraag wat vervolgens behandel sal word, is of hierdie metafisiese konstruksie die moontlikheid inhou om akrasia as 'n intra-wil-konflik te verduidelik.

Ek sal spesifiek na meer onlangse manifesterings van hierdie dialektiek kyk. Kommentatore wys daarop dat daar onderskei kan word tussen radikale en gematigde sienings in hierdie debat. Die radikale siening stel sigself voor as 'n poging om die self as metafisiese konstruk totaal af te takel. Die agterdog bestaan by hierdie siening dat die self niks meer as ' $n$ hol idee met geen realiteit is nie - dat die self ' $n$ gereïfiseerde skepping van die modernistiese ideologie is 
Die gematigde standpunt wil nie noodwendig bewustelik van die self ontslae raak nie - daar word eerder gepoog om die self sodanig te transformeer dat die onaanvaarbaarhede verbonde aan hierdie konstruk uitgeskakel kan word. Die primêre hipotese van die radikale standpunt is dat die mens merendeels ingesluit is in allerlei sosiale magsisteme wat sy gedrag determineer (Baynes et al., 1989: 8-10; Bernstein, 1985:12-13; Hollinger, 1994:113-115; Kavanaugh, 1993:305; Rosenau, 1992:42-44). Hiervolgens sou die oorsaak vir akrasia - soos in die geval van die parsialiste hierbo - gesoek kon word in die feit dat die self struktureel nie sterk genoeg is om die invloed van buite die self te weerstaan nie. Maar soos reeds genoem is, sal daar gepoog word om die dualisme te weerstaan met 'n dialektiese spel.

Ten einde die gesprek in fokus te kry, sal ek eerstens kyk na enkele sienings van die latere Michel Foucault wat tot die radikale kamp gereken word. Met die terugkyk op sy vroeere werk stel Foucault $(1982: 208-209,212)$ dat sy doel was om te fokus op die manier waarop ons kultuur subjekte uit mense gemaak het. Die kulturele magsisteme wat konstrueer, sê Foucault (1977:200-201), is op sigself subjekloos - dit is nie 'n menslike agent wat daaragter skuil nie maar 'n anonieme, polimorfe netwerk. Foucault (1977:137-138) gaan primêr van die standpunt uit dat die self as die oorsprong van menslike aksie nie eintlik bestaan nie. Interpretasies van Foucault dui ook daarop dat sy primêre teiken die gereifiseerde subjek is en dat hy probeer aantoon dat die subjek bloot 'n metateoretiese konsep of selfs metafisiese illusie is (Lemert \& Gillan, 1982:101; Colwell, 1994:58, 62, 64, 67).

Hierdie verwerping van 'n self skep egter probleme van sy eie. Die algemene kritiek teen die siening van Foucault is dat hy daarmee bevrydende aksies onmoontlik maak omdat hy nie voorsiening mak vir 'n subjek wat die beperkinge van die omgewing kan transendeer nie (Colwell, 1994:66; Taylor, 1985b:152-153, 167, 169-170). Dit is asof Foucault bewus is van hierdie probleem want hy skep (hoewel erg beskroomd) ook ruimte vir bevryding en subjektiwiteit. Foucault (1982:215-216; 1984:42-46) leer byvoorbeeld van die Verligting 'n sekere 'filosofiese etos', naamlik 'n 'permanente kritiek van die tyd waarin ons leef'. Hierdie kritiek is 'n kritiek wat voortdurend poog om die grense wat aan ons gegee is te transendeer. Dit vra na wat geidentifiseer kan word as partikulier en kontingent in dit wat vir ons voorgehou word as universeel en noodsaaklik. Hierdie algemene aanpak laat Foucault ook geld vir sy ondersoek na die self. Hy soek naamlik na dit wat nie noodsaaklik is in dit wat vir ons voorgehou word as die konstitusie van outonome subjekte nie. Die eerste implikasie van laasgenoemde kritiese aanpak is dat dit spreek van 'n soeke na vryheid van die sosiale sisteme wat ons inbind. Vryheid is egter iets wat moeilik los gesien kan word val 'n subjek wat poog om bevryding te bewerkstelling. Foucault (1982:208) erken dan ook dat hy 'gesoek het na die manier waarop die 
persoon homself in 'n subjek verander het'. Foucault (1982:221-222) erken verder die noodsaak van interaksie tussen die ekstra-self en 'n soort subjektiwiteit. Hy sien naamlik die verhouding tussen die self en sosiale sisteme as ' $n$ permanente interafhanklikheid tussen vryheid en mag. Vryheid word daarom die voorwaarde vir die bestaan van mag aangesien mag sonder die moontlikheid van verset daarteen, bloot net nog 'n deterministiese natuurmag word. Hiermee word die deur geopen vir bevrydende aksies aangesien Foucault nou erken dat daar in die kern van magsisteme 'n stryd om bevryding aan die gang is. Hy noem hierdie permanente stryd tussen magsisteme en die vryheid/wil 'n "agonisme"3. In hierdie dialektiek maak Foucault dus voorsiening vir 'n gedeeltelike herverskyning van die self/wil.

Charles Taylor se meer gematigde standpunt maak die bestaan van die wil van die begin af ' $n$ moontlikheid: sy argument is dat die belang wat aan die wil gegee word, die bewussyn van 'n innerlike ruimte binne die mens grootliks verhoog - 'n ruimte waar alle subjektiewe vermoèns gelokaliseer is. Hierdie hipotese veronderstel dus dat die wil geassosieer word met 'n gereifiseerde self. Taylor noem die ontwikkeling van die innerlike self 'n fatale stap, want dit gee uiteindelik aanleiding tot konsepte wat hy die disengaged self en punctual self noem. Albei hierdie konsepte gee uitdrukking aan die idee van 'n transendentale self wat sigself sodanig anders voel as die wêreld waarin ons woon dat dit poog om sigself van hierdie wêreld te ontworstel en ' $n$ universele a-tydse wêreld in te beweeg - vandaar die poging om 'n ontliggaamde, 'n gedesitueerde en ongeïnterpreteerde self aan ons voor te hou. Taylor wil hierdie konstruk aftakel deur daarop te wys dat die self nie onaangeraak gelaat word deur sy omgewing nie (Taylor, 1988:313-314; 1989a:127-132, 134-135, 137-140). Tog, ten spyte van sy kritiek is Taylor (1989a:176) nie gereed om innerlikheid totaal te verwerp as 'n metafisiese illusie nie. Dit het so deel geword van die Westerse manier van dink oor die mens dat ons dit kwalik kan ontkom. Daarom meen Taylor (1985a:6-7) dat ons nie van iets soos die disengaged self ontslae kan raak nie maar dat ons moet poog om dit te transformeer deur van die 'illusionêre pretensies' daarvan ontslae te raak. Foucaultiaanse volgelinge sien hierdie dubbelsinnige posisie van Taylor as eintlik maar 'n keuse vir 'n volbloed gereïfiseerde en dus super-self met absolute subjektiewe mag (Shapiro, 1986:312313, 322; Patton, 1989:263, 265-267; Connolly, 1985:371). Dit beteken dat hulle Taylor daarvan beskuldig dat hy nie ruimte laat vir die feit dat die self gevorm word deur magte van die ekstra-self soos wat Foucault suggereer nie.

3 Foucault se vertaler verduidelik dat "agonisme" Foucault se ncologisme is wat gebasecr is op die Grickse woord agoonisma wat stryd betcken 
Dit lyk inderdaad of Taylor (1985a:97-99, 102-103; 1985b:170-174; 199lb:295264) soms kies vir 'n soort Sartreaanse self wat sy situasie kan transendeer en van buite herskep. Omdat hy hom nie kan versoen met subjektiwiteit wat iewers in strukture vasgekeer is nie, lê Taylor klem op 'n sentrale subjektiewe kapasiteit, naamlik die interpretasievermoë van die mens. Hierdie vermoë, argumenteer hy, maak mense tot ' $n$ groot mate die oorsprong van betekenis. Mense gee oorsprong aan doelwitte, begeertes, afkeure, ensovoorts. Om uit hierdie identifisering van 'n kern vir die self af te lei dat Taylor volledig kies vir die almagtige transendentale self sou egter 'n fout wees, want hy het ook 'n duidelik ontwikkelde siening van die self as gesitueerd in en dus gedeeltelik gedetermineerd deur sy leefwêreld. Die manier waarop Taylor hierdie gesitueerdheid formuleer, kom neer op 'n dialektiek tussen die self en sy situasie. Taylor (1989a:35-38; 1989b:277; 1991:32-35) sien byvoorbeeld die sosiale gesitueerdheid van die mens as ' $n$ transendentale voorwaarde vir bestaan. Maar tegelyk stel hy dat die self in 'n dialogiese relasie tot sy gemeenskap staan. Verder is die self en gemeenskap, volgens Taylor $(1985: 234 ; 1989: 38)$, in taal gesitueerd. Maar tegelyk waarsku Taylor $(1989: 33-34,524)$ teen die radikale postmodernisme wat soms die indruk skep dat die mens eensydig deur taal gedetermineer word. Hy benadruk dat identiteit ook deur die persoon se self-interpretasies bepaal word. Dan sien Taylor (1989a:3-4, 16, 26, 27, 33) ook betekenishorisonne of raamwerke as die transendentale voorwaarde of onontkombare gesitueerdheid van die self. Weereens egter is die persoon se vermoë tot self-interpretasie vir Taylor (1989:390) die teëpool wat 'n eksterne determinering van die self en sy gedrag verhoed. En dan is dit ook so dat Taylor (1985a:100-101; 1991b:261262) van mening is dat ons ons emosies kan beheer (manipuleer) deur ons interpretasievermoë. Hy erken egter terselfdertyd dat hierdie 'skepping' van emosies beperk word deur die realiteit buite die self omdat ons emosies meesal reaksies op ons situasie is. Dit is duidelik dat Taylor homself nie skuldig maak aan 'n tradisionele modernistiese self wat losgedink en losgeworstel is van die invloed van die buite-self nie. Die interpretasievermoë van die self is nie sonder meer onafhanklik van die volle situasie van die mens nie. Meer presies moet ' $n$ mens sê dat Taylor eintlik 'n gedeeltelik gesitueerde self voorstel omdat sy veronderstelling is dat die situasie nie die self volledig determineer nie. Die gedeeltelike gesitueerdheid is terselfdertyd dus ook die self se gedeeltelike gedesitueerdheid. Taylor (1991a:66-69; 76-80) voorsien hiervolgens 'n dialektiese spel tussen self-determinering en determinering deur die buite-self wat 'n mate van ooreenstemming toon met die van die latere Foucault.

\subsection{Dialektiek is nie 'n verklaring van akrasia nie}

Teen 'n voorstel vir 'n dialektiese siening van akrasia kan twee besware ingebring word: Eerstens slaag die dialektiek nie heeltemal daarin om die eksterne konflik tussen die self en sy omgewing te oorkom en dus te voldoen aan 
die tradisionele siening van akrasia as 'n wil in konflik met homself nie. Tweedens is die permanente aard van die dialektiese konflik problematies - 'n permanent verswakte wil is ' $\mathrm{n}$ wil met ' $\mathrm{n}$ bepaalde krag en nie ' $\mathrm{n}$ wil wat momenteel swak optree nie.

Ek sal eerstens kyk na die beswaar dat 'n dialektiese monisme nie daarin sal slaag om uit te styg bo 'n konflik tussen die buite-self en self nie. Hierbo is geargumenteer dat Rorty veronderstel dat die akratiese konflik 'n konflik tussen die self en die buite-self is. Die idee dat akrasia ' $n$ konflik tussen die self en sy omgewing is, is egter 'n verwerping van die tradisionele beeld van akrasia wat veronderstel dat die konflik in die wil plaasvind. Rorty (1980:210-211) erken teen die einde van haar argument dat sy gevaar loop om die konflik te sien as tussen die wil en dit wat nie die wil is nie. Sy stel egter dat dit nie haar bedoeling is nie en dat die akratiese gedrag wat iemand kies omdat dit die maklikste lyk, nie noodwendig iets is wat nie sy oorsprong in die wil het nie. Om die waarheid te sê, sy sien vermoens wat die persoon laat neig na die akratiese alternatief ook as deel van sy karakter. Die rede kan hiervolgens as die deurslaggewende legitimeerder van die doelwitte van die self gesien word. Dit beteken egter nie dat ander aspekte van menswees nie ook deel vorm van die besluitnemingsproses nie. Wanneer die akratiese alternatief gekies word, is dit omdat 'n 'laere' vermoë van die mens die oorhand oor die persoon se dade kry. Die belangrike van hierdie verduideliking is die poging om die akratiese konflik binne die mens tussen veronderstelde laere en hoëre (rede) fasette van die persoonlikheid te plaas. Hierdie siening vind 'n meer volledige verduideliking in 'n dialektiese monisme. Die doel van die dialektiese spel is om die twee pole nader aan mekaar te bring en uiteindelik met mekaar te laat versmelt. Dit kan sover vorder dat selfs van 'n blote onderskeid tussen hoëre en laere aspekte, tussen 'n sentrum en 'n periferie gepraat word. Dit beteken dat as die self die sentrum is, die aanvanklike buite-self sy periferale aanhangsel vorm. Hiervolgens sou akrasia gesien kan word as 'n konflik tussen die self en sy periferie.

Waarnemers suggereer dat die verskynsel 'sentrering van die self' dui op twee soorte fokus. Dit kan eerstens 'n antroposentrisme veronderstel, dit wil sê die menslike self word as die sentrum van die wêreld gesien; dit kan die intersentrering van die self genoem word. Meer primêr egter is die tweede sentrering, naamlik die intra-sentrering van die self wat beteken dat een of ander aspek of dimensie van menswees (tradisioneel die rede) as die middelpunt van menswees gesien word (Bakker, 1982:91; Francke, 1993:7; Middleton \& Walsh, 1995:48; Sheridan, 1980:92-93; Smith, 1988:xxx; Taylor, 1987:44). Hierdie intrasentrering is niks anders as 'n hiërargisering waar 'n bepaalde aspek die hoëre kern van die self gemaak word nie. Dit beteken tegelyk dat die inter-sentrering van die self gebaseer word op die intra-sentrering van die self. Die intragesentreerde aspek (gewoonlik die rede) word die magsvermoë waarmee die 
mens homself verhef tot die sentrum van die wêreld. Die probleem van die intrasentrering van die self is dat dit steeds 'n eensydige en erg verskraalde prentjie van menswees gee omdat daar nie sekerheid is dat die periferale aspekte werklik tot die ware self behoort nie. Wanneer menswees in een aspek gesentreer is, is die ander apekte tot 'n mindere of meerdere mate uitgesluit uit die kern van menswees. Dit laat dus die moontlikheid dat akrasia steeds 'n min of meer eksterne konflik bly.

Huidige kritiek maak baie daarvan dat die self desentreer behoort te word. Die vraag is egter hoever hierdie desentrering gevoer kan word. Taylor (1989a:461$463,472-481$ ) argumenteer byvoorbeeld dat Foucault se radikalisme 'n fragmentering van die self beteken - dat daar op 'n verskeidenheid vlakke geleef word wat nie met mekaar versoen kan word nie. Volgens Taylor se gematigde standpunt is hierdie pluralisering van die self gewens tot op die punt waar 'n onaanvaarbare fragmentering van die self intree. Hy val daarom terug op die beeld van ' $n$ innerlike self waar die eenheid van die self gesetel is en wat as instrument vir die ekspressie van die ekstra-self diens doen. Wat meer is, Taylor (1985a:238-239; 1991a:81-82) veronderstel dat die dialektiek tussen self en situasie hıёrargıes van aard is. In hierdie hiërargie is dit - verrassend, in die lig van die beskuldiging dat Taylor van 'n transendentale subjek uitgaan, maar verstaanbaar in die lig van Taylor se kritiek van die disengaged self - nie die self wat die hoër posisie inneem nie, maar die situasie of buite-self. Die self word bloot die instrument waardeur die buite-self sigself uitdruk. Die self bly egter die enigste middel waardeur 'n groot deel van die realiteit van die buite-self sigself kan manifesteer. By Taylor word die inter-sentrering van die self bloot omgeswaai en word 'n steeds intra-gesentreerde self na die periferie uitgeskuif en 'n gesentreerde buite-self neem die plek in van die outonome self.

In die dialektiek tussen die self en die buite-self, soos deur Taylor voorsien, is daar dus nie werklik sprake van 'n versmelting van sekere aspekte van die buiteself tot ware aspekte van die mens nie. Dit lyk egter of dieselfde gesê kan word van Foucault se meer radikale standpunt. Colwell (1994:66-67) argumenteer dat Foucault se dialektiek tussen die bestaan en nie-bestaan van die self eintlik beteken dat die fokus steeds val op die gedeeltelike verdwyning van die self: Hy argumenteer dat daar nooit by Foucault sprake is van "the return of an originary subject ... there is only a continual retreat of this subject" (Colwell, 1994:66). Feller kritiek is dat Foucault se dialektiek, in veral sy latere fases, hom dwing om oor te beweeg na die stel van 'n estetiese self wat die absolute vryheid het om sigself te skep (Dews, 1989:38; Taylor, 1989:488-489). Die ironie van hierdie beweging in sy latere denke is dat Foucault hiermee nader beweeg aan die Sartreaanse self - 'n self met onbeperkte vryheid en mag. Die interessante van sowel Foucault as Taylor se sienings van die dialektiese spel tussen die self en die ekstra-self is dus die indruk dat albei in die loop van hul uiteensettings van 
Akrasia en die kontemporêre gesprek oor subjektiwiteit

hierdie dialektiek 'n omslag ondergaan. Taylor word aanvanklik deur Foucaultdissipels daarvan beskuldig dat hy niks minder is as 'n oudmodiese self-epigoon nie. In die loop van sy dialektiek blyk dit egter dat hy eintlik van plan is om 'n mindere instrumentele rol aan die innerlike self toe te ken. Foucault weer begin met die standpunt van die nie-self en eindig met 'n magtige selfskeppende subjek. Vir die begrip akrasia beteken hierdie dialektiese prentjie dat daar steeds nie 'n versmelting van die self en die buite-self plaasvind nie. Die enigste wat werklik gebeur het, is 'n posisie-omruiling wat impliseer dat die konflik waarin die self sigself bevind, steeds ekstern is. Dit is steeds nie ' $n$ konflik van die intra-self soos wat tradisionele akrasia impliseer nie. Hoewel Rorty se strategie om die buite-self in die sfeer van die self in te trek al 'n stap nader aan die tradisionele akrasiabegrip is, kan dit steeds die fout van 'n onoplosbare dialektiek begaan. En soos Taylor en Foucault se denke aantoon - so 'n dialektiek verander nie noodwendig van 'n eksterne na 'n intra-self-konflik/-verhouding nie.

Die tweede probleem van die dialektiese self is dat dit 'n permanente konflik voorstel in teenstelling to die akrasiabegrip wat 'n tydelik verlammende konflik voorsien - of dan minstens 'n konflik wat in beginsel opgelos kan word, veronderstel. In 'n dialektiese konsep gebeur dit selde dat die dialektiese spel tot 'n einde kom - dit bevestig sowel Taylor as Foucault ook in hul sienings van die verhouding tussen die dialektiek van die self en die buite-self. Die swakheid van 'n dialektiek is dat dit oënskynlik versand in die heen en weer skipper tussen die twee pole. 'n Toestand van eenheid/harmonie tussen die self en die buite-self sal nie sommer bereik word nie tensy een pool daarin slaag om die oorhand oor die ander te kry - wat op sy beurt 'n sentrering van die hoëre pool beteken. Die dialektiese formulering van die verhouding tussen die self en buite-self beteken dus dat dié twee, maar ook wilsterkte en akrasia, soos 'n Siamese tweeling aanmekaar vasgeheg is. Vir 'n verklaring van akrasia beteken dit dat swakheid van die wil 'n permanente deel van die self se mondering word. Volgens Taylor (1989:138) is die akratiese konsep van die wil inderdaad dan ook teken van 'n self wat in permanente spanning is. In die wêreld waarin ons leef, sê hy, van half-verstaan en weersprekende begeertes, is die wil net soveel die onafhanklike krag as wat dit die afhanklike element is wat gevorm word deur kragte van die ekstra-self. Die wil en buite-wil is in 'n sirkulêre verhouding - die lyn van oorsaak en gevolg is nie liniêr nie. Die konflik van die self wat tot akratiese gedrag aanleiding kan gee, is volgens hierdie siening van 'n relatief durende aard - dit is toe te skryf aan 'n strukturele fout wat deur die sogenaamde human condition loop.

Die idee dat akrasia niks anders is nie as 'n soort permanente strukturele fout in die self, lewer 'n onaanvaarbaar verdrukkende konsep van akrasia. Taylor (1989b:279-281) wys daarop dat ons by Foucault met 'n Janusbeeld van die self en magsisteme te doen het - bemagtiging en ontmagtiging van die self is twee 
kante van dieselfde munt. Volgens Taylor is die konsekwensie hiervan dat 'n belangrike swakheid in Foucault se siening van bevryding blootgelê behoort te word: die verbinding tussen bemagtiging en ontmagtiging word iets apriories dit bly nie 'n bloot kontingente en histories verbygaande verskynsel nie. Anders gestel, die permanente koppeling van 'n ontmagtigende omgewing met 'n self wat na bemagtiging streef, kom uiteindelik neer op 'n durende (half)verlamming van die self se wilsvermoë. Taylor noem dit 'n viktimisering van die self. Hoewel Taylor krities is oor die transendentale koppeling van mag en onmag by Foucault, dwing sy eie dialektiek hom om 'n soortgelyke struktuur vir die self te aanvaar. Taylor (1991a:66, 71-73, 76-77) voorsien dat 'n spanningvolle maar onlosmaaklike verhouding tussen die vrye skeppende vermoëns van die self aan die een kant, en - aan die ander kant - die sosiale en betekenishorisonne waarin die self gesitueerd is, ons kultuur bepaal. Horowitz (1987:61, 64-66, 72-74) kritiseer sowel Taylor as Foucault daarvoor dat hulle nie 'n visie kan gee op 'n radikaal vrye (en dus bemagtigde) self nie. Vryheid is nie radikaal nie omdat die mag wat aan die subjek gegee word, nie genoeg is nie. Horowitz maak egter dieselfde fout as hy in sy voorstel vir ' $n$ alternatief terugval op Marcuse se onderskeid tussen basiese en surplusrepressie. Hiervolgens is 'n minimum van sosiale repressie nodig om 'n subjek te skep. Maar, stel Horowitz, basiese repressie beteken nog nie dat 'n oormaat van repressie nodig is nie. Afgesien van die vaagheid van wat nou eintlik die verskil is tussen basiese en surplusrepressie, veronderstel hierdie siening steeds die kernfout van Marcuse se denke: kommentatore wys daarop dat Marcuse se nie-repressiewe orde nie kan bestaan sonder die repressiewe orde van oorvloed nie. Marcuse se absolute protes teen die repressiewe orde blyk uiteindelik nie so absoluut te wees nie en 'n radikale rewolusie nie so gewens nie. Om die waarheid te sê, vryheid word onmoontlik as dit nie 'n noodsaaklike stukkie onderdrukking insluit nie (King, 1972:136, Klapwijk, 1977:46; Zuidema, 1970:68-69). Die viktimisering van die self is steeds nie opgehef nie.

Laasgenoemde kritiek bring ons op die spoor van 'n fatale ontologiese veronderstelling in die siening van die parsiële en dialektiese verklaarders van akrasia. Vryheid, en vir sover vryheid geïdentifiseer word met die self, is onlosmaaklik gekoppel met iets wat eintlik die bestaan van die self/vryheid ontken of minstens daarmee in kompetisie is. Dit kan nie ontken word dat die self soms in konflik is met sy omgewing is nie, maar die siening dat self en buiteself tegelyk onlosmaaklik aan mekaar verbonde is maar ook in 'n oneindige konflik met mekaar is, dui op 'n kontradiksie. En hierdie kontradiksie beteken in die praktyk dat vryheid/self op 'n permanente basis deur die buite-self geviktimiseer word. Dus, indien aanvaar word dat akrasia 'n permanente toestand van die self is, word daarby veronderstel dat akrasia bestaan uit 'n permanente viktimisering van die self deur die buite-self. Dit is egter 'n vraag of die permanente struktuur van die verhouding tussen die self en sy omgewing so pessimisties gesien moet word. Die mens is per slot van rekening ook vir sy 
Akrasia en die kontemporêre gesprek oor subjektiwiteit

lewensonderhoud afhanklik van die omgewing. Vir 'n Christelike visie wat die goedheid van skepping en verhoudinge binne die skepping bely, is 'n veronderstelde gegewe en permanente konflik met sy omgewing asof laasgenoemde minder goed geskape is, onaanvaarbaar. Maar ook vir buiteChristelike standpunte vir wie die vryheid van die mens belangrik is en wat nie tevrede is met 'n siniese berusting in 'n geviktimiseerde self nie, sal hierdie konsep van akrasia onaanvaarbaar wees. Die konklusie moet dus wees dat akrasia nie gesien kan word as 'n permanente viktimisering van die self nie maar dat dit 'n prentjie moet gee van 'n self wat slegs tydelik in konflik met homself verkeer.

\subsection{Die 'verdigte' self}

In die plek van 'n onoplosbare dialektiek en 'n permanente hiërargiese struktuur van menslike vermoens moet eerder erken word dat kreatiwiteit, liggaamlikheid, interpretasievermoë en ook die mens se sosiale en morele situasie, almal op 'n manier deel vorm van essensiële menslike aspekte. Meer spesifiek, hierdie aspekte moet almal gesien word as subjektiewe vermoens. Stevenson (1981:89) wys daarop dat die nut van Sartre se klem op keusevryheid die feit is dat hy keuse en verantwoordelikheid verder uitbrei as wat tradisioneel aanvaar word. Die mens is nie net verantwoordelik vir sy rasionele aksies nie maar ook vir sy emosies en vir die sosiale groep waarin hy homself bevind. Maar as 'n persoon verantwoordelikheid neem vir sy emosies, liggaam en sosiale groep beteken dit dat hierdie aspekte in die subjektiwiteit van die persoon ingetrek word. En dit beteken dat die liggaam, sosiale groep en emosies deel kan word van die bemagtigende vermoens van die mens en nie bloot, soos tradisioneel aanvaar word, deel van die buite-self of periferale fout wat die mens verhoed om 'n totaal vrye en selfskeppende wese te wees nie. Hierby moet gevoeg word dat die wil of subjektiwiteit as die vermoë om die oorsprong van aksies te wees, gesien moet word as 'n kenmerk wat deel is van elke menslike vermoè. In dié verband is dit insiggewend dat Taljaard (1976:182-183) binne die sfeer van die Christelike filosofie argumenteer dat die wil 'n spesifieke krag is wat deel van die kern van menswees uitmak en wat daarvoor verantwoordelik is dat menslike aktiwiteite hul oorsprong by die mens self kry. Hy lê klem daarop dat alhoewel menslike aktiwiteite en die aspekte waaruit hulle ontstaan 'n verskeidenheid vertoon, die wil as oorsprongskrag of -vermoë gemeenskaplik aan almal is. Die desentrering van die self beteken dus nie ' $n$ verontsubjektivering van die mens nie maar wel 'n verdigting van die self. Waar 'n gesentreerde self eintlik 'n 'dun' self is in die sin dat subjektiwiteit gebaseer is op 'n enkele vernoè, is 'n gedesentreerde maar verdigte self ' $n$ meer omvattende siening van die subjektiwiteit van die mens.

Terselfdertyd moet daar ook afgestap word van die spanning tussen die self en die buite-self as 'n permanente struktuur vir menswees in hierdie wêreld. 
Hiermee word nie gesuggereer dat daar nie meer onderskei kan word tussen byvoorbeeld die individuele self en sy sosiale groep nie. Die eensydige siening dat die self en sy groep in kompetisie is om beheer van die self se gedrag, is egter verskralend. Dit kan toegegee word dat daar soms konflik in die self sal wees oor die vraag of hy moet konformeer aan sosiaal voorgeskrewe gedrag of nie. Aan die ander kant is dit egter ook so dat geïnternaliseerde sosiale norme deel is van die self se vermoëns soos wat sy vermoë om te redeneer of interpreteer, deel is van sy self. Anders gestel, sonder hierdie geinternaliseerde sosiale betekenishorison of lewens- en wêreldbeskouing, sal die individuele self verlore en sonder rigting wees in die wêreld waarin hy leef. Die verdigte self wat in die plek van die gesentreerde self voorgestel word, beteken onmiddellik dat die akratiese konflık veel meer tussen die aspekte van die self afspeel as wat dit 'n spanning tussen die self en die buite-self veronderstel. 'n Werklik verdigte self waarin daar nie 'n hiërargie van menslike aspekte veronderstel word nie, waar afgesien is van die intra-gesentreerde self, beteken ook dat afgesien kan word van die siening dat akrasia veroorsaak word deur 'n strukturele fout in die vermoëns van die self. Die hipotese van die strukturele fout veronderstel dat akrasia veroorsaak word deurdat sommige aspekte wat minder deel van die self en sy besluitnemingsvermoe is, die sentrale self van sy gekose trajek laat ontspoor.

Die idee van 'n gedesentreerde self kan die indruk skep dat die self gefragmenteer is, en dus per definisie 'n self in konflik is. So 'n radikalisering van die pluraliteit van menslike aspekte sou akrasia eerder die reel as die uitsondering - en die akratiese begrip uiteindelik sinloos - maak. Maar 'n gedesentreerde self hoef nie te eindig in 'n gefragmenteerde self nie. Taylor (1989:45-49) wys daarop dat ' $n$ gesonde selfbeeld of identiteit wat noodsaaklik is vir positiewe aksie veronderstel dat 'n mens sy lewe sal sien as 'n ontvouende narratief. Ten einde hierdie soort selfbeeld te hê, is dit nodig dat ons 'n bewustheid het vanwaar ons kom en waarheen ons op pad is. Fundamenteel vir ' $n$ ontvouende lewe is dat die rigting vorentoe bepaal word deur ' $n$ sin vir die 'goeie' wat ons as't ware die toekoms in trek. Hierdie sin vir die goeie het te doen met die basiese trou wat elke mens sweer. In Christelike terme gestel, die rigting van ons lewens is afhanklik van die religieuse verbondenheid van die persoon en die vraag is of die verbondenheid in die rigting van God is en of dit gerig is op ' $n$ afgod. Volgens Taylor is dit hierdie sentrale rigting wat die meer ondergeskikte vrae oor wat ons behoort te doen, bepaal. Dit sou ook kon beteken dat die verskillende vermoëns van die self geïntegreer word deurdat hulle gerig word deur die sentrale verbondenheid met 'n bepaalde rigting vir die lewe. Akrasia is hiervolgens ' $n$ konflik van die intra-self tussen sekere aspekte oor die rigting van iemand se lewe. 
Akrasia en die kontemporêre gesprek oor subjektiwiteit

\section{Slot}

Ek het in die begin gestel dat die konsep akrasia ons met twee probleme konfronteer wat ek gerieflikheidshalwe die vrae oor en van akrasia genoem het. Die vraag oor akrasia vra of daar werklik so 'n verskynsel soos die swakheid van die wil kan wees soos wat die tradisionele definisie van akrasia probeer voorgee. Akrasia veronderstel eerstens dat ' $n$ mens ' $n$ wilsvermoë besit en dat sy situasie van so ' $n$ aard is dat die besluite wat hiervolgens geneem word, wel uitgevoer kan word. Soms gebeur dit egter dat hy willens en wetens teen sy wilsbesluite in handel wat dan 'n geval van akrasia daarstel. Hierdie klassieke of tradisionele betekenis van die akrasiakonsep is reeds deur die Sokraties-Platoniese tradisie verwerp met die argument dat 'n persoon gemotiveer word deur die goeie wat hy met sy rasionele vermoë waarneem. Hierdie siening veronderstel met ander woorde dat die goeie iets buite die persoon is wat noodwendig gevolg sal word as hy dit waarneem. Die enigste fout wat kan insluip, is 'n onsuiwer of onvolkome waarneming van die goeie. Hierteenoor veronderstel die akrasiabegrip dat selfs in die geval waar die goeie duidelik en suiwer waargeneem en selfs gekies word, dit steeds kan gebeur dat daarteen gehandel word.

Die moderne uitlopers van die Sokraties-Platoniese tradisie manifesteer hulself onder andere in die naturalisme van Skinner se behaviorisme. Hier word die bestaan van ' $n$ self met ' $n$ inisierende wil effektief ontken. Dit beteken dat akrasia nie werklik moontlik is nie want die veronderstelling is dat die mens grootliks deur sy omgewing gedetermineer word en dat die vraag of die wil swak optree, irrelevant is. Hierteenoor veronderstel die moderne transendentalisme van iemand soos Sartre 'n self met absolute outonomie. Volgens hierdie siening besit die mens 'n selfskeppende vermoe wat beteken dat sy haarself kan kies in 'n lugleegte van gegewe altematiewe. Dit beteken dat sy haarself nooit werklik in eksistensiële konflikte bevind nie, in elk geval geen konflik wat nie deur middel van 'n self-skeppende keuse uit die weg geruim kan word nie. By gebrek aan so 'n egte innerlike konflik is akrasia in die oorspronklike sin van die woord nie moontlik nie. Die afleiding wat gemaak kan word, is dus dat akrasia net moontlik kan wees as die mens aan ons voorgehou word as iets tussen totale self-loosheid en absolute self-skeppende outonomie. Anders gestel: die self moet kan kies, maar die keuses wat gemaak word, is gegee en nie self geskep nie. Alleen in laasgenoemde geval sal egte konflik tussen die verskeie gegewe altematiewe moontlik wees. Dit is duidelik uit die bespreking van sowel Skinner as Sartre se argumente oor wie die mens is, dat sowel self-loosheid as outonomie mank gegaan het aan innerlike weersprekings. Meer presies: self-loosheid moet uiteindelik toegee dat iets soos die self wel 'n rol te speel het in ons siening van die mens. Net so moet 'n standpunt van absolute outonomie ten laaste ruimte laat vir 'n gegewe struktuur vir die menslike situasie. Hierdie weersprekings suggereer dat die sienings van self-loosheid en outonomie nie werklik realistiese 
alternatiewe is nie. Dit lyk dus of die vraag oor akrasia (bestaan dit of nie) bevestigend beantwoord kan word omdat 'n wil kan bestaan maar dat dit tegelyk 'n wil is wat ook 'n onvermoë kan toon om wilsbesluite uit te voer

Die tweede vraag rondom die verskynsel van akrasia kan die vraag van akrasia genoem word. Die vraag van akrasia is na die aard van die konflik wat in akrasia plaasvind. Dit is met ander woorde 'n opvolgvraag wat 'n positiewe antwoord op die vraag oor akrasia veronderstel. In die kontemporêre antwoorde op die vraag van akrasia is daar ' $n$ neiging om 'n konflik tussen die self en sy omgewing te konstrueer. Dit is alreeds die kern van sowel Skinner as Sartre se worsteling rondom outonomie en heteronomie. Dit lyk egter nie na die konflik wat die akrasiakonsep in gedagte het nie. 'n Kru voorbeeld van die konflik tussen self en omgewing sou die volgende wees: Iemand neem die wilsbesluit om maan toe te spring, maar as gevolg van die beperkinge wat die aardse omgewing hom oplê, kan hy hierdie wilsbesluit nie uitvoer nie. Dit sou moeilik wees om hierdie as 'n voorbeeld van akrasia te beskryf. 'n Akratiese voorbeeld sou eerder diè wees van 'n soldaat wat voor 'n geveg besluit het om heldhaftig te veg maar tydens die geveg lafhartig opgetree het. Uit hierdie twee voorbeelde kan 'n mens aflei dat die konflik van akrasia nie tussen die wil en die omgewing is nie maar tussen verskillende moontlikhede wat die omgewing bied. In die voorbeeld van die maansprong is die spring na die maan nie werklik 'n moontlikheid wat die omgewing bied nie. In die keuse tussen heldhaftigheid en lafhartigheid is eersgenoemde egter duidelik 'n realiseerbare alternatief. Dit is, met ander woorde, 'n konflik wat sigself intra-wil afspeel.

Dit het in onlangse voorstellings van die mens gewild geword om die konflik tussen die self en omgewing deur middel van 'n dialektiese proses te probeer oplos. Die bedoeling van so 'n dialektiek is om die self met sy omgewing te versmelt. Vir die problematiek van akrasia sou dit die ideale uitweg gewees het aangesien dit sou beteken dat heelwat wat nou as 'n eksterne konflik ervaar word eintlik 'n konflik van die intra-wil sou wees. Die sukses van die dialektiese proses is egter onder verdenking omdat dit nie lyk of dit versmelting kan bewerkstellig nie. Dit lyk hoogstens moontlik om 'n hiërargie van sentrum en periferie te bewerk. So 'n hiërargie veronderstel egter steeds 'n verhouding wat meer lyk na 'n permanente eksterne konflik - die wilsbesluit word in die kern geneem met die doel om in beheer te wees van die periferie. Hoewel met 'n kleiner afstand tussen self en buite-self gewerk word, is die konflik nog steeds ekstern. Tog bring die worsteling rondom die dialektiese proses ons 'n stappie nader in die sin dat hierdie gesprek die idee van 'n desentrering van die self gewild gemaak het. Die desentrering van die self veronderstel 'n verspreiding van die subjektiewe of wilsvermoë van die mens oor meerdere menslike aspekte. Hiermee word die beginsel aanvaar dat aspekte wat voorheen van die self uitgesluit was, nou ingetrek kan word tot deel van menswees. 'n Goeie voor- 
beeld hiervan is sosiale genormeerdheid. Die konflik wat sosiale norme soms by mense veroorsaak, kan volgens die gesentreerde self-model gesien word as 'n eksterne konflik, dit wil sê 'n konflik tussen die self en sy samelewing. Volgens 'n gedesentreerde model kan die feit dat sosiale norme in die persoon geïnternaliseer is, egter gesien word as deel van die skepping van die self. Die self is met ander woorde ook sy sosiale norme en waardes. Sonder geinternaliseerde sosiale norme is iemand gewoon nie in staat om in 'n bepaalde omgewing te funksioneer nie. Dit het die betekenis dat as daar konflik bestaan tussen 'n mens se biologiese, emosionele of rasionele aspekte aan die een kant en haar sosiale norme aan die ander kant, dit gesien kan word as ' $n$ intra-konflik wat inderdaad tot akrasia aanleiding kan gee.

'n Verduideliking van akrasia wat steeds bevestigend antwoord op die vraag oor akrasia (of dit bestaan al dan nie) moet dus minstens die volgende twee argumente bevat.

- Die eerste is dat akrasia intra-wil plaasvind. Dit beteken nie dat die akratiese konflik 'n kontekslose, of omgewing-ontkoppelde oorsprong het nie. Die konteks van die persoon gee steeds die keuses waartussen die wil moet kies. Die belangrikste van hierdie keuses is waarskynlik die keuse tussen goed en kwaad, of vir 'n Christen, 'n keuse vir of teen God. Hierdie keuse is nie iets wat die mens uit homself kan voortbring nie. Indien dit die geval sou wees, sou dit nie 'n egte keuse wees nie want met dieselfde vermoë om keuses te skep, kan keuse-alternatiewe ook ongedaan gemaak word. Die feit dat die keuse intra-wil plaasvind, beteken egter dat die keuse nie tussen determinering deur die konteks of self-determinering is nie. In die geval van 'n situasie (konteks) wat aan iemand geen keuse oorlaat nie, wat in vele gevale wel waar kan wees, kan daar nie sprake wees van akrasia indien hy nie sy eie wil kan volg nie.

- Die tweede been van die verduideliking van die akratiese konflik bestaan uit 'n argument waarin 'n wyer skopus aan die wil gegee word as wat tradisioneel veronderstel word. Hiermee word gestel dat vele van die konflikte wat gewoonlik gesien word as konflikte tussen die self en sy konteks eerder geïnterpreteer kan word as konflikte wat sigself binne die wil van 'n persoon afspeel.

\section{Bibliografie}

BAKKER, R. 1982. Wijsgerige antropologie van de twintigste eeuw. Assen : Van Gorcum BAYNES, K., BOHMAN, J., McCARTHY, T eds. 1989 After philosophy - end or transformation Cambridge, Massachusetts : MIT

BERNSTEIN, R J 1985. Beyond objectivism and relativism - science, hermeneutics, and praxis. Oxford : Blackwell 
M.F. Heyns

BOTHA, ME 1990 Metateoretiese perspektiewe op die sosiale wetenskappe. Potchefstroom : $\mathrm{PU}$ vir $\mathrm{CHO}$

COL.WELL, C 1994 The retreat of the subject in the late Foucault. Philosophy Todoy, 38(1/4):56-69.

CONNOLLY, W.E. 1985. Taylor, Foucault, and otherness Political Theory, 13(3):365-376

DEWS, P. 1989. The return of the subject in late Foucault Radical Philosophy, 51:37-41

EVANS, C.S. 1979 Preserving the person Downers Grove, Illinois : InterVarsity Press.

FOUCAULT, M. 1977 Language, counter-memory, practice Ithaca, New York : Cornel University Press.

FOUCAULT, M. 1982 The subject and power. (/n Dreyfus, H.L. \& Rabinow, P. eds Michel Foucault: Beyond structuralism and hermeneutics Brighton, Sussex : The Harvester Press. p. 208-226.)

FOUCAULT, M 1984 What is Enlightenment? (In Rabinow, $\mathrm{P}$ ed The Foucault reader New York : Pantheon Books. p. 32-50)

FRANCKE, S. 1993. Room for the Other - about the de-centred subject. Unpublished paper delivered at the Institute for Christian Studies, Toronto, Canada

HOLLINGER, R 1994. Postmodernism and the social sciences - A thematic approach Thousand Oaks : Sage Publications

HOROWITZ, G. 1987. The Foucaultian impasse: No sex, no self, no revolution. Political Theory, 15(1):61-80.

KAVANAUGH, J.F. 1993. On the possibilities of a post-modern anthropology. The Modern Schoolman, 70(4):305-313

KING, R 1972. The party of Eros: Radical social thought and the realm of freedom Chapel Hill : The University of North Carolina

KLAPWIJK, J 1977. Dialektiek der Verlichting: een verkenning in het neomarxisme van de Frankfurter Schule Amsterdam: Van Gorcum

KLAPWIJK, J 1987. Oriëntatie in de nieuwe filosofie. Assen : Van Gorcum.

LEMERT, C.C. \& GILLAN, G 1982. Michel Foucault - Social theory and transgression New York : Columbia University Press.

MELE, A R. 1986. Is akratic action unfree? Philosophy and Phenomenological Research, 46(4):673-679

MIDDLETON, J R \& WALSH, B J 1995. Truth is stranger than it used to be - Biblical faith in a postmodern age Downers Grove, Illinois : InterVarsity Press

PATTON, P 1989 Taylor and Foucault on power and freedom Political Studies, 37 260 276

PLATO 1982 Protagoras. (In Buchanan, S ed. The portable Plato. Harmondsworth Penguin. $p$ 45-117.)

RORTY, A O. 1980. Akrasia and conflict. Inquiry, 23:193-212.

ROSENAU, P M 1992 Post-modernism and the social sciences - insights, inroads, and intrusions. Princeton, New Jersey : Princeton University Press

SARTRE, J P 1990. Existentialism and humanism. London : Methuen.

SHIAPIRO, M J 1986 Charles Taylor's moral subject Polltical Theory, 14(2) 311-324

SHERIDAN, A. 1980 Michel Foucault - The will to truth. London: Tavistock Publications

SKINNER, B.F. 1972a Beyond freedom and dignity London: Jonathan Cape

SKINNER, B F 1972b Cumulative record - a selection of papers New York : AppletonCentury-Crofts

SMITH, P. 1988 Discerning the subject Minneapolis : University of Minnesota Press

STEVENSON, L 1981. Seven theories of human nature New York: Oxford University Press

TALJAARD, J A.L 1976. Polished lenses Potchefstroom : Pro Rege Press 
TAYLOR, C 1985a Philosophical papers I: Human agency and language Cambridge Cambridge University Press

TAYLOR, C 1985b Philosophical papers II: Philosophy and the human sciences Cambridge : Cambridge University Press

TAYLOR C. 1988. The moral topography of the self. (In Messer, S B., Sass, L A. \& Woolfolk, R.L eds. New Brunswick: Rutgers University Press p. 298-320.)

TAYLOR, C 1989a Sources of the self - making of the modern identity. Cambridge : Cambridge University Press

TAYLOR, C. 1989b. Taylor and Foucault un power and freedom: a reply. Political Studies, $37: 277-281$.

TAYLOR, C. 1991a The malaise of modernity. Concord, Ontario : Anansi.

TAYLOR, C 199lb. The person (In Carrithers, M., Collins, S. \& Lukes, S. eds The category of the person Cambridge : Cambridge University Press p 257-281)

TAYLOR, M C 1987 Erring - a postmodern a/theology. Chicago : The University of Chicago Press

WALSH, J.J 1971. The Socratic denial of akrasia (In Vlastor, G ed The philosophy of Socrates. New York : Anchor Books. p. 234-263.)

WATSON, G 1977. Skepticism about weakness of will. The Philosophcal Revew, 86:316339

ZUIDEMA, S U 1970. De revolutionaire maatschappijkritiek van Herbert Marcuse. Amsterdam : Buiten \& Schipperheijn 